\title{
Pengaruh Current Ratio dan Quick Ratio Terhadap Return On Asset
}

\section{(Studi Kasus Sub Sektor Makanan dan Minuman yang Terdaftar di Bursa Efek Indonesia)}

\author{
Delvi Rahma Novianti, Dr. Juhaini Alie, MM, Endah Dewi Purnamasari, SE., MM \\ Universitas Indo Global Mandiri, Palembang, Indonesia \\ Email: delvirahma99@gmail.com,juhaini@uigm.ac.id,endahdps86@gmail.com
}

\begin{abstract}
This study aims to analyze the effects of current ratio (CR) and quick ratio (QR) on return on assets (ROA) in the food and beverage sub-sector listed on the Indonesia Stock Exchange. Financial report data were collected through documentation, literature study, and observation. This study implemented multiple linear regression methods to analyze data. The results of the investigation prove that partially CR has a significant effect on ROA. On the other hand, QR has no significant effect on ROA. Simultaneously, CR and QR have a significant effect on ROA. This research offers empirical evidence on the discussion of $\mathrm{CR}, \mathrm{QR}$, and ROA especially for the food and beverage industry.
\end{abstract}

Keywords: Current Ratio, Quick Ratio, Return On Assets, Financial Reports

\section{Pendahuluan}

Suatu perusahaan yang di dirikan tujuan utama adalah untuk mencari keuntungan dengan memperoleh laba yang maksimal agar kelangsungan hidup perusahaan dapat dipertahankan dan meningkatkan keuntungan bagi para pemegang sahamnya. Seperti peneliti (Tanzil \& Darwin, 2017) sebelumnya mengungkapkan bahwa setiap perusahaan memiliki tujuan untuk mencari profitabilitas. kelangsungan hidup suatu perusahaan tergantung dari kemampuan perusahaan dalam menghasilkan profit atau laba perusahaan tersebut. Profitabilitas sangat penting bagi setiap pengguna laporan keuangan, khususnya investor, dan kreditor. Teknologi sudah sangat berkembang pesat sehingga persaingan bisnis lebih sulit. Peneliti (Surmadewi \& Saputra, 2019) dan (Felany \& Worokinasih, 2018) ini juga mengatakan bahwa Persaingan dunia usaha dalam perekonomian pasar bebas sekarang ini semakin ketat. Hal ini disebabkan semakin banyaknya perusahaan yang berdiri dan berkembang sesuai dengan bertambahnya jumlah unit usaha ataupun meningkatnya kegiatan ekonomi yang ditandai dengan meningkatnya kebutuhan pasar. 
Vol. 2 No. 4, November 2021

\section{Tabel 1. Ikhtisar Laporan Keuangan \\ Subsektor Makanan dan Minuman Periode 2017-2019 \\ (Dalam Rupiah)}

\begin{tabular}{|c|c|c|c|c|c|}
\hline No. & Kode & Tahun & Laba & Aktiva & Persediaan \\
\hline \multirow{3}{*}{1.} & \multirow{3}{*}{ MYOR } & 2017 & $1,630,953,830,893$ & $14,915,849,800,251$ & 1.825 .267 .160 .976 \\
\hline & & 2018 & $1,760,434,280,304$ & $17,591,706,426,634$ & $3,351,796,321,991$ \\
\hline & & 2019 & $2,039,404,206,764$ & $19,037,918,806,473$ & $2,790,633,951,514$ \\
\hline \multirow{3}{*}{2.} & \multirow{3}{*}{ ALTO } & 2017 & $62,849,581,665$ & $1,109,383,971,111$ & $125,753,902,334$ \\
\hline & & 2018 & $33,021,220,862$ & $1,109,843,522,344$ & $121,306,183,449$ \\
\hline & & 2019 & $7,383,289,239$ & $1,103,450,087,164$ & $115,601,575$ \\
\hline \multirow{3}{*}{3.} & \multirow{3}{*}{ PSDN } & 2017 & $32,150,564,335$ & $690,979,867,049$ & $237,836,194,381$ \\
\hline & & 2018 & $46,599,426,588$ & $697,657,400,651$ & $213,814,837,421$ \\
\hline & & 2019 & $25,762,573,884$ & $763,492,320,252$ & $167,177,342,163$ \\
\hline \multirow{3}{*}{4.} & \multirow{3}{*}{ CAMP } & 2017 & $41,408,953,772$ & $1.211,184,522,659$ & $74,981,135,207$ \\
\hline & & 2018 & $65,166,017,439$ & $1,004,275,813,783$ & $281,133,628,265$ \\
\hline & & 2019 & $171,000,649,858$ & $1,054,077,089,978$ & $171,000,649,858$ \\
\hline \multirow{3}{*}{5.} & \multirow{3}{*}{ ADES } & 2017 & 38,242 & 840,236 & 107,977 \\
\hline & & 2018 & 52,958 & 881,275 & 109,137 \\
\hline & & 2019 & 83,855 & 822,375 & 78,755 \\
\hline \multirow{3}{*}{6.} & \multirow{3}{*}{ CEKA } & 2017 & $107,420,886,839$ & $1,392,636,444,501$ & $415,268,436,704$ \\
\hline & & 2018 & $92,649,656,779$ & $1,168,956,042,706$ & $332,754,905,703$ \\
\hline & & 2019 & $215,459,200,242$ & $1,393,079,542,074$ & $262,081,262,42$ \\
\hline \multirow{3}{*}{7.} & \multirow{3}{*}{ CLEO } & 2017 & $50,173,730,829$ & $660,917,775,322$ & $737,089,070$ \\
\hline & & 2018 & $62,261,752,474$ & $833,933,861,594$ & $1,152,314,490$ \\
\hline & & 2019 & $130,756,461,708$ & $1,245,144,303,719$ & $251,178,388$ \\
\hline \multirow{3}{*}{8.} & \multirow{3}{*}{ PACR } & 2017 & $370,909,777$ & $140,807,574,027$ & $19,224,822,862$ \\
\hline & & 2018 & $8,385,167,515$ & $117,423,511,774$ & $13,459,099,075$ \\
\hline & & 2019 & $10,257,599,104$ & $124,735,506,555$ & $9,266,198,227$ \\
\hline \multirow{3}{*}{9.} & \multirow{3}{*}{ DLTA } & 2017 & $279,772,635$ & $1,340,842,765$ & $178,863,917$ \\
\hline & & 2018 & $338,129,985$ & $1,523,517,170$ & $205,396,087$ \\
\hline & & 2019 & $317,815,177$ & $1,425,983,722$ & $207,460,611$ \\
\hline \multirow{3}{*}{10.} & \multirow{3}{*}{ ROTI } & 2017 & $135,364,021,139$ & $4,559,573,709,411$ & $50,264,253,246$ \\
\hline & & 2018 & $127,171,436,363$ & $4,393,810,380,883$ & $65,127,735,601$ \\
\hline & & 2019 & $236,618,557,420$ & $4,682,083,844,951$ & $83,599,374,391$ \\
\hline \multirow{3}{*}{11.} & \multirow{3}{*}{ HOKI } & 2017 & $47,964,112,940$ & $576,963,542,579$ & $71,875,799,840$ \\
\hline & & 2018 & $90,195,136,265$ & $758,846,556,031$ & $142,212,647,161$ \\
\hline & & 2019 & $103,732,133,972$ & $848,676,035,300$ & $156,029,530,465$ \\
\hline \multirow{3}{*}{12.} & & 2017 & $35,543,173$ & $31,619,514$ & $3,261,635$ \\
\hline & ICBP & 2018 & $4,658,781$ & $34,367,153$ & $4,001,277$ \\
\hline & & 2019 & $5,360,029$ & $38,709,314$ & $3,840,690$ \\
\hline & & 2017 & $5,079,264$ & $88,400,877$ & $9,792,768$ \\
\hline 13. & INDF & 2018 & $4,961,851$ & $96,537,796$ & $11,644,156$ \\
\hline & & 2019 & $5,902,729$ & $96,198,559$ & $9,658,705$ \\
\hline & & 2017 & 711,681 & $5,175,896$ & 682,624 \\
\hline 14. & ULTJ & 2018 & 701,607 & $5,555,871$ & 708,773 \\
\hline & & 2019 & $1,035,865$ & $6,608,422$ & 987,927 \\
\hline & & 2017 & $216,024,079,834$ & $2,342,432,443,196$ & $2,709,606,207$ \\
\hline 15. & STTP & 2018 & $255,088,886,091$ & $1,250,806,822,918$ & $6,010,469,155$ \\
\hline & & 2019 & $482,590,522,840$ & $1,165,406,301,686$ & $663,841,924$ \\
\hline
\end{tabular}

Sumber: Diolah Oleh Peneliti (2020)

Berdasarkan nilai tabel diatas laporan keuangan periode 2017-2019 dapat dilihat dari lima

Publisshed by: 
belas perusahaan subsektor makanan dan minuman yang terdaftar pada Bursa Efek Indonesia. Lima belas perusahaan tersebut memperoleh laba, aktiva dan persediaan dengan hasil yang berbeda-beda, hasil laba tertinggi diperoleh PT Mayora Indah Tbk pada tahun 2019 sebesar Rp 2,039,404,206,764 pada tahun 2017-2018 mengalami peningkatan sebesar Rp 129,480,499,411. Aktiva tertinngi diperoleh PT Mayora Indah Tbk pada tahun 2019 sebesar Rp 19,037,918,806,473 pada tahun 2017-2018 mengalami peningkatan sebesar Rp 2,675,856,626,634. Persediaan tertinggi diperoleh PT Mayora Indah Tbk pada tahun 2018 sebesar $\mathrm{Rp} 3,351,796,321,991$ pada tahun 2018 mengalami peningkatan sebesar Rp 1,526,529,161,016 pada tahun 2019 terjadi penurunan sebesar Rp 561,132,370,477. Laba terendah diperoleh pada PT Akasha Wira Internasional Tbk pada tahun 2017 sebesar Rp 38,242 pada tahun 2018-2019 mengalami peningkatan sebesar Rp 30,897. Aktiva terendah diperoleh PT Akasha Wira Internasional pada tahun 2019 sebesar Rp 822,375 pada tahun 2017-2018 mengalami peningkatan sebesar Rp 41,039. Persediaan terendah diperoleh PT Akasha Wira Internasional Tbk pada tahun 2019 sebesar Rp 78,755 pada tahun 2017-2018 mengalami peningkatan sebesar Rp 1,160.

Berdasarkan tabel di atas, menunjukkan fenomena bahwa aktiva dan persediaan lima belas perusahaan sub sektor makanan dan minuman mengalami fluktuasi selama beberapa periode sehingga menyebabkan laba perusahaan ikut mengalamani kenaikan dan penurunan. Dari hasil pengukuran rasio, apabila rasio lancar rendah, dapat dikatakan bahwa perusahaan kurang modal untuk membayar utang. Namun, apabila hasil rasio tinggi, belum tentu perusahaan dalam kondisi baik. Bisa saja hal ini terjadi karena kas tidak digunakan dengan sebaik mungkin. Dalam penelitian ini rasio likuiditas diwakili oleh Current Ratio (CR), rasio ini menunjukkan tingkat keamanan suatu perusahaan. Alasan pemilihan variabel ini dalam penelitian yaitu untuk mengukur kemampuan perusahaan dalam membayar kewajiban jangka pendek yang akan segera jatuh tempo. Jika current ratio rendah berarti perusahaan mengalami kekurangan modal untuk membayar utang-utangnya yang segera jatuh tempo. Namun jika current ratio tinggi belum tentu kondisi perusahaan dalam keadaan baik. Hal ini dapat saja terjadi karena kas tidak digunakan sebaik mungkin. Pengaruh current ratio dengan pertumbuhan laba menunjukkan bahwa semakin tinggi current ratio maka laba yang dihasilkan perusahaan akan semakin rendah. Profitabilitas dalam penelitian ini diproksikan dengan Return on Asset (ROA), yang dapat menunjukkan kemampuan perusahaan mengelola seluruh aset yang dimiliki untuk memperoleh keuntungan. Dengan kata lain, $R O A$ dapat digunakan untuk mengukur seberapa besar jumlah laba yang diperoleh dari setiap dana yang tertanam dalam total aset (Hery, 2015)

Berdasarkan uraian diatas, maka penulis tertarik untuk membuat laporan akhir dengan masalah yang berjudul "Pengaruh Current Ratio dan Quick Ratio Terhadap Return On Asset (Studi Kasus Sub Sektor Makanan dan Minuman Yang Terdaftar Di Bursa efek Indonesia)".

Berdasarkan identifikasih masalah penelitian maka peneliti merumuskan permasalahan sebagai berikut:

1. Bagaimana pengaruh Current ratio terhadap Return on asset?

2. Bagaimana pengaruh Quick ratio terhadap Return on asset?

3. Bagaimana pengaruh Current ratio dan Quick ratio terhadap Return on asset?

Tujuan dari penelitian ini adalah untuk mengetahui, menganalisis dan membuktikan: 
1. Untuk mengetahui pengaruh Current ratio terhadap Return on asset.

2. Untuk mengetahui pengaruh Quick ratio terhadap Return on asset.

3. Untuk mengetahui pengaruh Current ratio dan Quick ratio terhadap Return on asset.

\section{Tinjauan Pustaka}

\subsection{Teori Manajemen Keuangan}

Menurut (Fahmi, 2015) "Manajemen Keuangan merupakan penggabungan dari ilmu dan seni yang membahas, mengkaji dan menganalisis tentang bagaimana seorang manager keuangan dengan mempergunakan seluruh sumberdaya perusahaan untuk mencari dana, mengelola dana dan membagi dana dengan tujuan memberikan profit atau kemakmuran bagi para pemegang saham dan suistainability (keberlanjutan) usaha bagi perusahaan."

Menurut (Musthafa, 2017) Manajemen keuangan menjelaskan tentang beberapa keputusan yang harus dilakukan, yaitu keputusan investasi, keputusan pendanaan atau keputusan pemenuhan kebutuhan dana, dan keputusan kebijakan deviden.

\subsection{Teori Kinerja Keuangan}

Menurut Prastowo yang dikutip oleh Putri Hidayatul Fajrin (2016) menyebutkan unsur dari kenerja keuangan perusahaan adalah unsur yang berkaitan secara langsung dengan pengukuran kinerja perusahaan yang disajikan pada laporan laba rugi, penghasilan bersih seringkali digunakan sebagai ukuran kinerja atau sebagian dasar bagi ukuran lainnya.

Menurut (Hery, 2016) "Pengukuran kinerja merupakan salah satu komponen penting didalam sistem pengendalian manajemen untuk mengetahui tingkat keberhasilan perusahaan dalam mencapai tujuan yang telah ditetapkan, baik tujuan jangka pendek maupun tujuan jangka panjang".

\subsection{Rasio Likuiditas}

Rasio likuiditas merupakan suatu indikator mengenal kemampuan perusahaan-perusahaan membayar semua kewajiban financial jangka pendek pada saat jatuh tempo dengan menggunakan aset lancar yang tersedia. Likuiditas tidak hanya berteman dengan keadaan keseluruhan keuangan perusahaan, tetapi juga berkaitan dengan kemampuannya menggunakan aset lancar tertentu menjadi uang kas. Rasio likuiditas menjelaskan mengenai kesanggupan perusahaan untuk melunasi hutang jangka pendek tingkat likuiditas yang tinggi menunjukan kemampuan melunasi utang jangka pendek. Dari definisi diatas dapat disimpulkan bahwa likuiditas adalah rasio yang mengukur kemampuan perusahaan untuk memenuhi semua kewajiban jangka pendek yang telah jatuh tempo.

Pengertian rasio likuiditas menurut (Arief Sugiono \& Edi Untung, 2016) "Rasio likuiditas adalah rasio yang bertujuan untuk mengukur kemampuan perusahaan dalam memenuhi kewajiban jangka pendeknya. Menurut (Periansya, 2015) "Rasio likuiditas adalah rasio yang digunakan untuk memenuhi kewajiban finansial jangka pendek". Adapun jenis-jenis rasio yang ada didalam rasio Likuiditas antara lain:

a. Rasio lancar (Current Ratio)

Current ratio adalah rasio yang menunjukkan kemampuan perusahaan dalam memenuhi kewajiban jangka pendeknya (utang lancar).

b. Quick Ratio (Acid Test ratio)

Quick Ratio merupakan rasio uji cepat yang menunjukkan kemampuan perusahaan 
membayar kewajiban jangka pendek dengan aktiva lancar tanpa memperhitungkan persediaan karena persediaan memerlukan waktu relatif lebih lama untuk diuangkan disbanding asset lain.

c. Cash Ratio

Cash Ratio merupakan alat untuk mengukur seberapa besar uang kas yang tersedia untuk membayar hutang yang dapat ditunjukkan dari tersedianya dana kas atau setara dengan kas seperti rekening giro.

\subsection{Profitabilitas}

Profitabilitas adalah tingkat keuntungan atau laba bersih yang mampu dicapai oleh perusahaan pada saat menjalankan operasional atau kegiatan perusahaanya. Profitabilitas menjelaskan pendapatan yang dimiliki perusahaan dimanfaatkan untuk membiayai investasi atau penanaman modal. Profitabilitas menunjukkan kemampuan dari modal yang diinvestasikan dalam keseluruhan aktiva untuk menghasilkan keuntungan bagi investor. Profitabilitas merupakan faktor yang dipertimbangkan dalam menentukan struktur modal perusahaan. Hal ini dikarenakan perusahaan yang memiliki profitabilitas tinggi cenderung menggunakan hutang yang relatif kecil karena laba ditahan yang tinggi sudah memadai untuk membiayai sebagian besar kebutuhan pendanaan. Semakin besar tingkat keuntungan atau laba menunjukkan semakin baik manajemen dalam mengelola perusahaan (Sutrisno, 2017)". Adapun jenis-jenis rasio yang ada didalam rasio Likuiditas antara lain:

\section{a. Return on Assets}

Return on Assets merupakan kemampuan perusahaan untuk memperoleh laba dengan menggunakan semua aktiva yang dimiliki perusahaan. Dalam $R O A$, laba yang diukur berupa laba kotor sebelum bunga dan pajak atau EBIT dari aktiva yang dipakai. Semakin besar rasio ini maka kondisi perusahaan semakin baik. Rasio ini disebut juga rentabilitas ekonomis yang mengindikasikan kemampuan asset yang dimiliki untuk memperoleh tingkat pengembalian atau pendapatan. Rentabilitas Ekonomi dengan kata lain menunjukkan kemampuan total aset dalam menghasilkan laba sehingga efektifitas perusahaan dalam memanfaatkan seluruh sumber daya bisa terlihat.

\section{b. Return on Investment}

Return on Investment merupakan kemampuan perusahaan untuk memperoleh keuntungan berupa laba bersih setelah pajak (EAT) agar bisa menutup investasi yang dikeluarkan. Rasio ini menilai jumlah laba bersih setelah pajak yang dihasilkan dibandingkan dengan setiap satu rupiah investasi yang dikeluarkan. Semakin besar rasio ini berarti kondisi perusahaana semakin baik. Return on investment bisa dikatakan berupa perbandingan antara laba bersih setelah pajak dengan total aktiva yang tersedia di dalam perusahaan. Semakin besar rasio ini berarti kinerja perusahaan semakin baik.

\section{c. Return on Equity (ROE)}

Return on Equity (ROE) merupakan perbandingan antara laba bersih sesudah pajak dengan total ekuitas berupa pengukuran dari penghasilan (income) yang tersedia bagi para pemilik perusahaan (baik pemegang saham biasa maupun pemegang saham preferen) terhadap modal yang telah diinvestasikan pada suatu perusahaan. Return on equity menunjukkan kemampuan perusahaan dalam mengelola modal sendiri (net worth) secara efektif serta mengukur laba dari investasi pemilik modal sendiri atau pemegang 
saham perusahaan. ROE menampilkan rentabilitas modal atau rentabilitas usaha.

\section{d. Net Profit Margin (NMP)}

Net profil margin NPM merupakan rasio yang menghitung sejauh mana kemampuan perusahaan menghasilkan laba bersih pada tingkat penjualan tertentu. NPM yang semakin tinggi maka kinerja perusahaan akan semakin produktif dan efisien dalam menekan biaya untuk meningkatkan laba dari penjualan, sehingga akan meningkatkan kepercayaan investor untuk menanamkan modalnya pada perusahaan tersebut.

\subsection{Kerangka Pemikiran}

Kerangka pemikiran penelitian yang dikembangkan seperti tersaji pada gambar berikut ini:

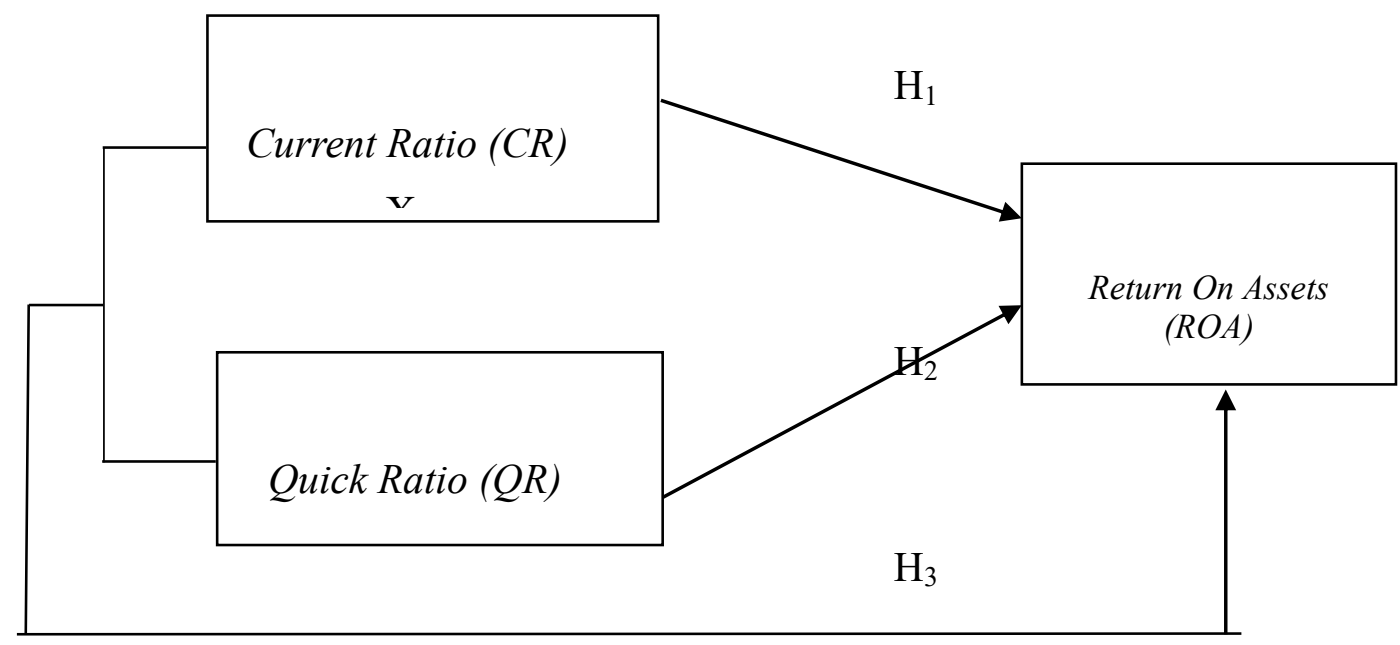

Gambar 1

Paradigma Penelitian

Penelitian ini bertujuan untuk menguji bagaimana pengaruh current ratio dan quick ratio terhadap return on assets. Ada dua variabel yang di uji dalam penelitian tersebut, yaitu: current ratio dan quick ratio (variable independent) dan return on assets (variable dependent). Variable current ratio dan quick ratio diduga berpengaruh terhadap return on assets subsektor makanan dan minuman yang terdaftar di Bursa Efek Indonesia. Oleh sebab itu, peneliti akan melakukan penelitian lebih lanjut untuk mengatahui pengaruh current ratio dan quick ratio terhadap return on assets subsektor makanan dan minuman yang terdaftar di Bursa Efek Indonesia.

\subsection{Hipotesis}

Menurut Sugiyono dalam (Iswara, 2017) Hipotesis merupakan jawaban sementara terhadap rumusan masalah penelitian, oleh karena itu rumusan masalah penelitian biasanya disusun dalam kalimat pertanyaan.

Berdasarkan kerangka penelitian diatas maka hipotesis penelitian ini adalah sebagai berikut: 
$\mathrm{H}_{1}$ : Diduga Current ratio berpengaruh terhadap Return on asset

$\mathrm{H}_{2}$ : Diduga Quick ratio berpengaruh terhadap Return on asset

$\mathrm{H}_{3}$ : Diduga Current ratio dan Quick ratio berpengaruh terhadap Return on asset

\section{Metode Penelitian}

Dalam penelitian ini penulis akan membahas permasalahan mengenai pengaruh current ratio dan quick ratio tehadap return on asset sub sektor makanan dan minuman yang terdaftar di Bursa Efek Indonesia. Jenis data yang digunakan adalah data kuantitatif, data kuantitatif adalah data yang dihitung dan diukur secara langsung berupa angka dan nilai Data diperoleh dari laporan keuangan perusahaan subsektor makanan dan minuman yang terdaftar di Bursa Efek Indonesia periode 2017-2019. Sumber data digunakan dalam penelitian ini adalah data sekunder data yang diperoleh dari laporan keuangan.

Objek dalam penelitian ini adalah perusahaan sub sektor makanan dan minuman yang terdaftar di Bursa Efek Indonesia periode 2017-2019. Populasi penelitian ini sebanyak 24 perusahaan subsektor makanan dan minuman, dan memilih sebanyak 15 perusahaan sub sektor makanan dan minuman yang memenuhi kriteria untuk dijadikan sampel. Teknik analisis menggunakan Uji Asumsi Klasik, Uji Normalitas, Uji Multikolinieritas, Uji Autokeralasi, Uji Heteroskedastisitas, Uji Parsial (Uji T), Uji Simultan (Uji F), Regresi linier berganda, Koefisien Korelasi (R), Koefisien Determinasi (R2).

Dalam penelitian ini peneliti mengambil sampel sebanyak 15 perusahaan. Perusahaan yang dijadikan sampel sebagai berikut :

Tabel 2

Sampel Penelitian

\begin{tabular}{|c|l|l|}
\hline No & Kode & \multicolumn{1}{|c|}{ Nama Perusahaan } \\
\hline 1. & MYOR & PT Mayora Indah Tbk \\
\hline 2. & ALTO & PT Tri Bayan Tirta Tbk \\
\hline 3. & PSDN & PT Prasidha Aneka Niaga Tbk \\
\hline 4. & CAMP & PT Campina Ice Cream Industry Tbk \\
\hline 5. & ADES & PT Akasha Wira International Tbk \\
\hline 6. & CEKA & PT Wilmar Cahaya IndonesiaTbk \\
\hline 7. & CLEO & PT Sariguna Primatirta Tbk \\
\hline 8. & PCAR & PT Praima Cakrawala Abadi Tbk \\
\hline 9. & DLTA & PT Multi Bintang Indonesia Tbk \\
\hline 10. & ROTI & PT Nippon Indonesia Corpindo Tbk \\
\hline 11. & HOKI & PT Buyung Poetra Sembada Tbk \\
\hline
\end{tabular}

Publisshed by: 
Vol. 2 No. 4, November 2021

\begin{tabular}{|c|c|l|}
\hline 12. & ICPB & PT Indofood CBP Sukses Makmur Tbk \\
\hline 13. & INDF & PT Indofood Sukses Makmur Tbk \\
\hline 14. & ULTJ & PT Ultra Jaya Milk Industry Tbk \\
\hline 15. & STTP & PT Siantar Top Tbk \\
\hline
\end{tabular}

Sumber: $\underline{w w w . i d x . c o . i d}$

\section{Hasil dan Diskusi}

\subsection{Hasil Uji Normalitas}

Uji normalitas digunakan untuk mengetahui apakah populasi data berdistribusi normal atau tidak. Uji ini digunakan untuk mengukur data bersekala ordinal, interval, dan hasil.

\section{Gambar 4.1}

\section{Normal Probability Plot}

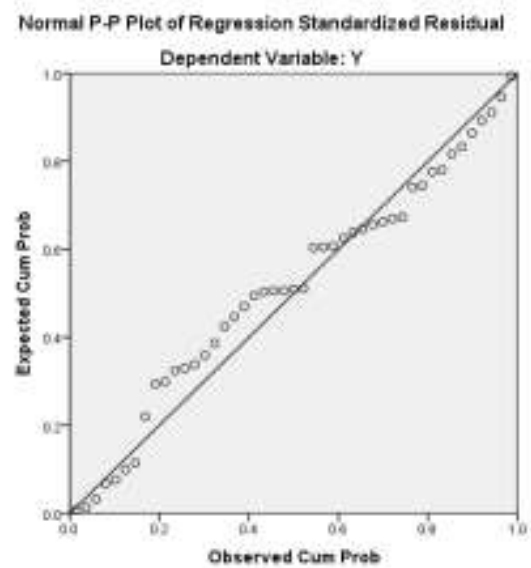

\section{Sumber: Pengolahan penulis}

Berdasarkan gambar 4.1 di atas, bahwa data dalam model regresi dengan variabel dependent return on asset mempengaruhi asumsi normalitas data dan titik-titik pada grafik menyebar di sekitar garis diagonal dan mengikuti arah garis diagonal pada grafik normal P-P Plot sehingga daapat disimpulkan bahwa data yang digunakan dalam penelitian memenuhi uji normalitas. Jadi data yang digunakan sangat baik. 


\subsection{Hasil Uji Multikolinieritas}

\section{Tabel 3 \\ Hasil Uji Multikolinieritas Coefficients $^{\mathrm{a}}$}

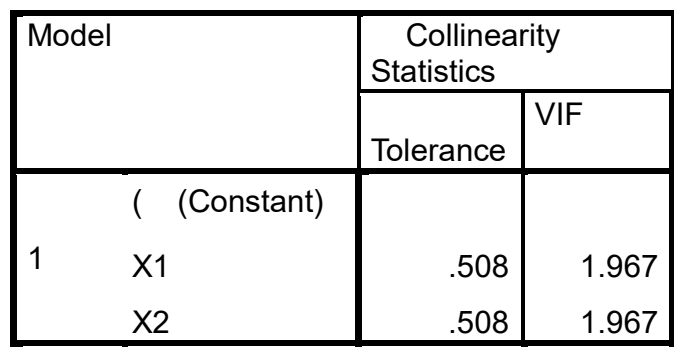

a. Dependent Variable: $Y$

Berdasarkan Tabel 3 diatas, menunjukan bahwa tidak ada satu variabel bebas yang memiliki nilai tolerance kurang dari 0,10 . Kondisi tersebut berarti bahwa tidak ada korelasi antar variable independent yang nilainya lebih dari 95\%. Hasil perhitungan VIF juga menunjukan kondisi yang sama, yaitu semua variable bebas memiliki nilai VIF dibawah 10. Nilai VIF dari masing-masing variabel independent, yaitu current rasio sebesar 1,967 dan quick rasio sebesar 1,967, sehingga dapat disimpulkan bahwa seluru variable independent dalam penelitian ini tidak terdapat andanya indikasi gejala multikolinieritas.

\subsection{Hasil Uji Autokorelasi}

\section{Tabel 4}

\section{Hasil Uji Autokorelasi}

\begin{tabular}{|l|l|l|lr|r|r|}
\hline Model & $R$ & $\begin{array}{c}\mathrm{R} \\
\text { Square }\end{array}$ & $\begin{array}{c}\text { Adjusted } \\
\text { Square }\end{array}$ & $\begin{array}{c}\text { Std. Error of } \\
\text { the Estimate }\end{array}$ & Durbin-Watson \\
\hline 1 & $.727^{2}$ & .528 & & .506 & 3.75382 & 1.642 \\
\hline
\end{tabular}

a. Predictors: (Constant), X2, X1

b. Dependent Variable: $Y$

\section{Sumber: Pengolahan penulis}

Hasil uji dari Durbin-Watson sebesar 1,642 nilai ini akan dibandingkan dengan nilai tabel menggunakan tingkat signifikansi 5\%. Jumlah sample (n) 45 dan jumlah variabel independent $2(\mathrm{k}=2)$. Dari tabel Durbin-Watson dapat diketahui bahwa nilai Durbin-Watson berada dibatas bawah (dl) 1,6148 dan batas atas (du) 2,3852.

\subsection{Hasil Uji Heteroskedastisitas}

Bersadarkan hasil pengujian heteroskedastisitas pada gambar 2, menunjukan bahwa tidak adanya pola tertentu dalam grafik scatterplot, kondisi tersebut dapat dilihat dari penyebaran data (titik) yang terjadi secara acak, baik dibawah maupun diatas not pada sumbu Y, sehingga dapat diambil kesimpulan bahwa model regresi dinyatakan baik dan layak untuk digunakan karena tidak terjadi hetorestisidas. Kesimpulan yang didapat dari analisis data tersebut adalah tidak terdapat adanya gejala heterokedastisitas dalam penelitian ini 


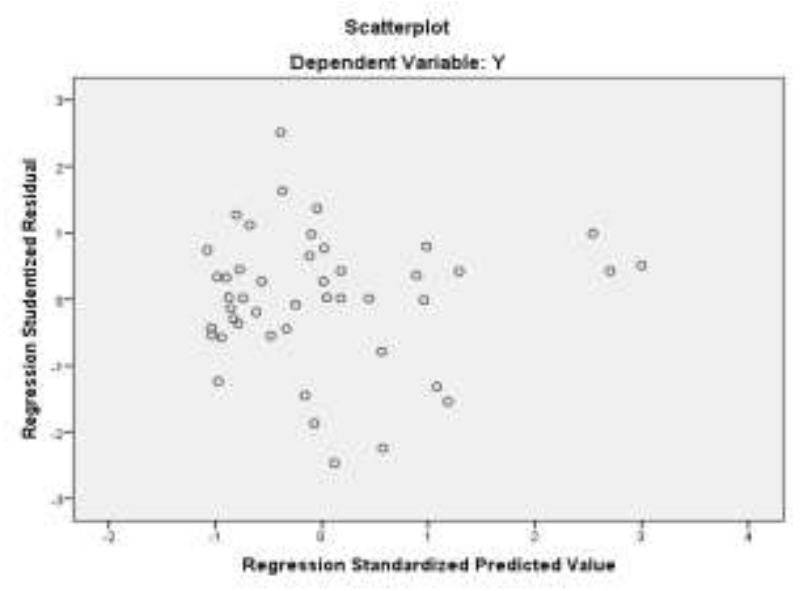

Gambar 2 scatterplot

\section{.4 .5 Uji Persial (uji T)}

Tabel 5

Uji Hipotesis

Coefficients $^{\mathrm{a}}$

\begin{tabular}{|c|c|c|c|c|c|c|}
\hline \multirow{2}{*}{\multicolumn{2}{|c|}{ Model }} & \multicolumn{2}{|c|}{ Unstandardized Coefficients } & \multirow{2}{*}{$\begin{array}{l}\text { Standardized } \\
\text { Coefficients } \\
\text { Beta } \\
\end{array}$} & \multirow[t]{2}{*}{$\mathrm{T}$} & \multirow[t]{2}{*}{ Sig. } \\
\hline & & $\mathrm{B}$ & Std. Error & & & \\
\hline \multirow{3}{*}{1} & (Constant) & 3.417 & 1.004 & & 3.403 & .001 \\
\hline & $\mathrm{X} 1$ & .019 & .004 & .656 & 4.409 & .000 \\
\hline & $\mathrm{X} 2$ & .003 & .005 & .097 & 651 & .519 \\
\hline
\end{tabular}

a. Dependent Variable: $Y$

Sumber: Pengolahan penulis

Pada Tabel 5 dihasilkan t-hitung sebesar 4.409 pada tingkat sig sebesar 0.000 . hasil uji tersebut dikaitkan dengan hipotesis yang diajukan dalam penelitian ini.

Kriteria diterimanya hipotesis apabila:

- Jika t-hitung $>$ t-tabel sig $<0,05$, maka $\mathrm{H}_{1}$ diterima

- $\quad$ Taraf nyata $=5 \%$ derajat kebebasan $(\mathrm{df})=(\alpha / 2 ; n-K-1)=(0,05 / 2 ., 45-3-1)=(0,025 ., 41)=$ 2,01954 .

Keterangan:

$\mathrm{K}=$ jumlah variabel

$\mathrm{N}=$ jumlah sampel

1. Diketahui nilai sig untuk pengaruh current ratio $\left(\mathrm{X}_{1}\right)$ terhadap return on asset $(\mathrm{Y})$ adalah sebesar $0,000<0,05$ dan nilai t-hitung 4,409 $>$ t-tabel 2,01954, sehingga dapat disimpulkan bahwa $\mathrm{H}_{1}$ diterima yang berarti current ratio $\left(\mathrm{X}_{1}\right)$ berpengaruh secara parsial terhadap Return 
on asset (Y) pada sub sektor makanan dan minuman yang terdaftar di Bursa Efek Indonesia.

2. Diketahui nilai sig untuk quick ratio $\left(\mathrm{X}_{2}\right)$ terhadap return on asset $(\mathrm{Y})$ adalah sebesar $0,0519>0,05$ dan nilai t-hitung $0,0651<\mathrm{t}$-tabel 2,01954, sehingga dapat disimpulkan bahwa $\mathrm{H}_{2}$ ditolak yang berarti quick ratio $\left(\mathrm{X}_{2}\right)$ tidak berpengaruh secara parsial tergadap Return on asset $(\mathrm{Y})$ pada sub sektor makanan dan minuman yang terdaftar di Bursa Efek Indonesia.

\subsection{Uji Simultan (Uji F)}

Tabel 6

Uji F simultan ANOVA $^{\mathrm{a}}$

\begin{tabular}{|ll|r|l|r|l|l|}
\hline Model & & \multicolumn{1}{|c|}{ Sum of } & Df & \multicolumn{1}{|l|}{$\begin{array}{l}\text { Mean } \\
\text { Square }\end{array}$} & F & Sig. \\
\hline \multirow{4}{*}{1} & Regression & 662.194 & 2 & 331.097 & 23.497 & $.000^{\circ}$ \\
& Residual & 591.827 & 42 & 14.091 & & \\
& Total & 1254.021 & 44 & & & \\
\hline
\end{tabular}

a. Dependent Variable: $Y$

b. Predictors: (Constant), $\mathrm{X}_{2}, \mathrm{X}_{1}$

\section{Sumber: Pengolahan penulis}

Dengan dasar pengambilan keputusan (Sujarweni, 2015):

Pengambilan keputusan berdasarkan nilai probabilitas:

Jika signifikan $\alpha<$ tingkat kesalahan $(\alpha<0,05)$, maka H3 diterima.

Pengambilan keputusan berdasarkan nilai f-hitung:

Jika f-hitung > f-tabel maka H3 diterima

Pengambilan keputusan berdasarkan f-hitung:

Jika f-hitung $<$ dari f-tabel maka H3 ditolak

Dengan penentuan f-tabel:

Derajat kepercayaan 5\% dengan uji dua sisi, dimana:

$\mathrm{V} 1=\mathrm{K}=2(\mathrm{~K}=$ jumlah variabel independent $)$

$\mathrm{V} 2=\mathrm{n}-\mathrm{K}-1=45-2-1=42 \rightarrow$ f-tabel $(=2 ; 42)$

Maka, didapat nilai f-tabel $=3,22$

Karena nilai f-hitung 23,497 > nilai f-tabel $(3,22)$ dan nilai signifikan sebesar $0,000<0,05$, maka H3 diterima, sehingga dapat disimpulkan bahwa current ratio dan quick ratio berpengaruh secara simultan terhadap return on asset. 
Tabel 7

Hasil Analisis Regresi Berganda Coefficients $^{\mathrm{a}}$

\begin{tabular}{|c|c|c|c|c|c|c|}
\hline \multirow{2}{*}{\multicolumn{2}{|c|}{ Model }} & \multicolumn{2}{|c|}{ Unstandardized Coefficients } & \multirow{2}{*}{$\begin{array}{l}\text { Standardized } \\
\text { Coefficients } \\
\text { Beta }\end{array}$} & \multirow[t]{2}{*}{$\mathrm{T}$} & \multirow[t]{2}{*}{ Sig. } \\
\hline & & $\mathrm{B}$ & Std. Error & & & \\
\hline & (Constant) & 3.417 & 1.004 & & 3.403 & .001 \\
\hline 1 & $\mathrm{X} 1$ & .019 & .004 & .656 & 4.409 & .000 \\
\hline & $\mathrm{X} 2$ & .003 & .005 & .097 & .651 & .519 \\
\hline
\end{tabular}

Dependent Variable: $Y$

\section{Sumber: Pengolahan penulis}

Bersadarkan data Tabel 7 dimana hasil analisis regresi diperolah persamaan regresi sebagai berikut:

$$
Y=3,417+0,019 X_{1}+0,003 X_{2}
$$

Hasil analisis regresi linier berganda yang masih berbentuk angka akan dijelaskan dalam bahasa yang mudah dipahami sebagaimana berikut ini:

Nilai konstanta sebesar 3,417 berarti jika variabel current ratio dan quick ratio bernilai 0 , maka return on asset akan bernilai sebesar 3,417. Sehingga dapat disimpulkan bahwa tanpa ada variabel current ratio dan quick ratio maka return on asset akan sebesar 3,417 dan menunjukan hasil yang positif.

Variabel current ratio mempengaruhi return on asset sebesar 0,019 atau berpengaruh secara positif yang artinya jika variabel current ratio meningkat satu, maka berpengaruh terhadap return on asset akan meningkat sebesar 0,019 .

Variable quick ratio mempengaruhi return on asset sebesar 0,003 atau berpengaruh secara positif yang artinya jika variabel quick ratio meningkat 1, maka berpengaru terhadap return on asset akan meningkat sebesar 0,003.

\section{8 koefisien korelasi}

Teknik analisis data yang digunakan dalam penelitian ini ialah analisis korelasi berganda atau hubungan antara dua atau lebih variabel independent dengan satu atau lebih variabel dependent. (Fauzi, Dencik, Asiati, 2019).

\section{Tabel 9}

\section{Hasil Koefisien Korelasi}

Model Summary

\begin{tabular}{|l|l|l|l|c|}
\hline Model & $\mathrm{R}$ & $\begin{array}{c}\mathrm{R} \\
\text { Square }\end{array}$ & $\begin{array}{l}\text { A djusted } \mathrm{R} \\
\text { Square }\end{array}$ & $\begin{array}{c}\text { Std. Error of } \\
\text { the Estimate }\end{array}$ \\
\hline 1 & $.727^{\mathrm{a}}$ & .528 & .506 & 3.75382 \\
\hline
\end{tabular}

a. Predictors: (Constant), $\mathrm{X}_{2}, \mathrm{X}_{1}$

b. Dependent Variable: $Y$

Sumber: Pengolahan Penulis

Publisshed by: 
Berdasarkan Tabel 9, diperolah hasil koefisien korelasi $(\mathrm{R})=0,727$ atau 72,7\%. Dari hasil perhitungan tersebut menunjukan bahwa tingkat keeratan variabel $\mathrm{X}$ ke variabel $\mathrm{Y}$ berarti kuat.

\section{9 koefisien determinasi $\left(R^{2}\right)$}

Koefisien determinasi ini digunakan untuk mengetahui seberapa besarnya persentase keeratan antar variabel terhadap variabel dependen. Besarnya presentase pengaruh sama variabel independent terhadap nilai variabel dependent dapat diketahui dari besarnya koefisien determinasi $\left(\mathrm{R}^{2}\right)$ persamaan regresi angka koefisien determinasi dilihat dari hasil perhitungan spss sebagai berikut:

Tabel 10
Hasil Uji Koefisien Determinasi
Model Summary

\section{Sumber: Pengolahan penulis}

Dari Tabel 10 menunjukan bahwa nilai $\mathrm{R}^{2}$ sebesar 0,528 atau 52,8\% menunjukan bahwa variabel return on asset yang dapat dijelaskan oleh current ratio dan quick ratio adalah $52,8 \%$, sedangkan 0,472 atau $47,2 \%$ sisa nya dijelaskan oleh faktor lain di luar variabel penelitian.

\subsection{Pembahasan}

\subsubsection{Pengaruh Current Ratio $\left(X_{1}\right)$ Terhadap Return On Asset $(Y)$}

Berdasarkan hasil uji statistik t yang disajikan dalam tabel 4.4 menunjukan bahwa current ratio memiliki nilai t-hitung lebih besar dari t-tabel $(4,409>2,01954)$ dengan nilai signifikan $(0,000)$ yang lebih kecil dari $(0,005)$. Hasil ini menunjukan bahwa current ratio berpengaruh signifikan terhadap return on asset. Hasil penelitian ini sejalan dengan hasil penelitian Rifany, D. (2019) yang menyatakan bahwa variabel current ratio berpengaruh signifikan terhadap return on asset. Namun hasil penelitian ini bertentangan dengan hasil penelitian Supardi, H (2018) yang menyatakan bahwa current ratio secara persial tidak berpengaruh terhadap retun on asset. Dari hasil penelitian dapat disimpulkan bahwa current ratio peningkatan yang diikuti dengan peningkatan retun on asset. Current ratio meningkat dikarenkan perusahaan mampu mengoptimalkan modal kerja untuk menjalankan kegiatan operasionalnya yang akan berdampak pada meningkatnya laba. Artinya setiap kenaikan current ratio maka akan diikuti dengan kenaikan return on asset, begitu juga dengan sebaliknya apabila current ratio mengalami penurunan maka akan diikuti dengan penurunan nilai return on asset. Semakin besar rasio lancar, maka menunjukan semakin besar kemampuan perusahaan untuk memenuhi kewajiban jangka pendeknya. Hal ini menunjukan perusahaan melakukan penempatan dana 
yang besar pada sisi aktiva lancar. Penempatan dana yang terlalu besar pada sisi aktiva memiliki dua efek yang sangat berlainan. Di satu sisi, likuiditas perusahaan semakin baik. Namun disisi lain, perusahaan kehilangan kesempatan untuk mendapatkan tambahan laba, karena dana yang seharusnya digunakan untuk investasi yang menguntungkan perusahaan, dicadangkan untuk memenuhi likuiditas. Pada penelitian ini, perusahaan sub sektor makanan dan minuman memiliki current ratio yang tinggi yang berarti bahwa semakin produktifnya asset yang dimiliki perushaan sehingga efektifitasnya meningkat ditandai dengan meningkatnya return on asset.

\subsubsection{Pengaruh Quick Ratio $\left(X_{2}\right)$ Terhadap Return On Asset ( $Y$ )}

Berdasarkan uji statistik t yang disajikan pada tabel 4.4 menunjukan bahwa quick ratio memiliki nilai t-hitung lebih kecil dari t-tabel $(0,0651<2,01954)$ dengan nilai signifikan $(0,0519)$ yang lebih besar dari $(0,005)$. Hasil ini menunjukan bahwa quick ratio tidak berpengaruh signifikan terhadap return on asset. Hasil penelitian ini sejalan dengan hasil penelitian Fadilah, N (2017) yang menyatakan bahwa quick ratio tidak berpengaruh secara parsial terhadap return on asset. Namun hasil penelitian bertentangan dengan hasil penelitian Jessica, H. S. (2019) yang menyatakan bahwa quick ratio secara persial berpengaruh signifikan terhadap return on asset. Tidak adanya pengaruh signifikan variabel quick ratio terhadap return on asset dikarenakan antara peningkatan quick ratio dan return on asset tidak terjadi keseimbangan. Hal ini menunjukan bahwa variabel quick ratio dan retun on asset memiliki perubahan yang tidak profesional. Agar quick ratio dapat meningkatkan retun on asset maka perusahaan harus mampu memaksimalkan pengalokasian dana yang menganggur pada peningkatan produktifitas perusahaan seperti melakukan investasi jangka pendek sehingga perusahaan mampu meningkatkan keuntungan sehingga perusahaan dapat menghasilkan laba yang maksimal dari dana yang menganggur atau tidak produsktif sehingga perusahaan mampu mengalokasikan dana untuk memenuhi kewajiban dari pengalokasian dana dan untuk memenuhi kewajiban dan dari keuntunga investasi jangka pendek yang dilakukan perusahaan.

\subsubsection{Pengaruh Current Ratio (X1) dan Quick Ratio (X2) Terhadap Return On Asset (Y)}

Berdasarkan uji statistik t yang disajikan pada tabel 4.4 menunjukan bahwa pengujian secara silmultan antara variabel current ratio dan quick ratio terhadap return on asset dengan nilai signifikan $0,008<0,005$ dan nilai f-hitung 23,497 $>$ f-tabel 3,22. Hasil ini menunjukan bahwa variabel $\mathrm{X}$ secara bersama-sama mempengaruhi secara signifikan terhadap variabel Y. Hasil penelitian ini sejalan dengan hasil penelitian Amelia, P (2014) yang menyatakan bahwa pengaruh current ratio dan quick ratio berpengaruh secara signifikan terhadap return on aseet, Namun hasil penelitian bertentangan dengan hasil penelitian Silvia, D (2019) yang menyatakan bahwa pengaruh current ratio dan quick ratio tidak berpengaruh secara signifikan terhadap return on aseet. Current ratio merupakan salah satu rasio likuiditas, yaitu rasio yang bertujuan untuk mengukur kemampuan suatu perusahaan dalam memenuhi kewajiban jangka pendeknya. Semakin tinggi CR suatu perusahaan berarti semakin kecil resiko kegagalan perusahaan dalam memenuhi kewajiban jangka pendeknya. Current ratio ini menunjukan tingkat keamanan kreditor jangka pendek, atau kemampuan perusahaan untuk membayar hutang-hutang tersebut. Current ratio yang terlalu tinggi menunjukan kelebihan uang kas atau aktiva lancar lainnya dibandingkan dengan yang dibutuhkan sekarang atau tingkat likuiditas yang rendah daripada aktiva lancar dan sebaliknya). Semakin besar rasio lancar, maka menunjukan semakin besar kemampuan perusahaan untuk memenuhi kewajiban 
jangka pendeknya. Hal ini menunjukan perusahaan melakukan penempatan dana yang besar pada sisi aktiva lancar. Penempatan dana yang terlalu besar pada sisi aktiva memiliki dua efek yang sangat berlainan. Di satu sisi, likuiditas perusahaan semakin baik, namun di sisi lain perusahaan kehilangan kesempatan untuk mendapatkan tambahan laba, karenadana yang seharusnya digunakan untuk investasi yang menguntungkan perusahaan, dicadangkan untuk memenuhi likuiditas perusahaan. Quick ratio atau rasio cepat modal menggambarkan sampai sejauh mana modal pemilik dapat menutupi hutang-hutang kepada pihak dapat menutupi hutang-hutang kepada pihak luar dan merupakan rasio yang mengukur hingga sejauh mana perusahaan dibiayai dari hutang.

\section{Kesimpulan}

Berdasarkan data yang diperoleh dan diolah kembali, maka hasil penelitian, tentang pengaruh current rasio dan quick ratio terhadap return on asset (studi kasus sub sektor makanan dan minuman yang terdaftar di bursa efek Indonesia) dan dapat disimpulkan bahwa:

1. Pengujian secara parsial variabel current ratio mempunyai pengaruh signifikan terhadap return on asset. Hal tersebut dibuktikan dengan nilai signifikan sebesar 0,000 $<0,05$ dan nilai t-hitung 4,409 $>$ t-tabel 2,01954.

2. Pengujian secara parsial variabel quick ratio tidak berpengaruh signifikan terhadap return on asset dengan nilai signifikan sebesar 0,0519>0,05 dan nilai t-hitung 0,0651 $<$ t-tabel 2,01954.

3. Pengujian secara silmultan antara variabel current ratio dan quick ratio terhadap return on asset dengan nilai signifikan $0,008<0,005$ dan nilai f-hitung 23,497 $>\mathrm{f}$ tabel 3,22 sehingga variabel $\mathrm{X}$ secara bersama-sama mempengaruhi secara signifikan terhadap variabel Y.

Bersadarkan hasil dan kesimpulan yang telah dijabarkan sebelumnya, maka saran yang diberikan peneliti untuk pihak-pihak yang berkepentingan adalah sebagai berikut:

a. Bagi perusahaan

Dalam menjalankan perusahaan, sebaiknya perusahaan lebih memperhatikan pengelolaan quick ratio perusahaan karena hasil penelitian menunjukan quick rasio perusahaan yang rendah dan itu akan mempengaruhi return on asset perusahaan. Perusahaan juga harus memperhatikan pengelolaan persediaannya agar dapat meningkatkan return on asset perusahaan.

b. Bagi peneliti berikutnya

Diharapkan bagi penelitian selanjutnya dapat diterapkan untuk semua bidang usaha. Penelitian selanjutnya juga diharapkan tidak hanya terbatas hanya perusahaan sub sektor makanan dan minuman. Variabel yang diteliti diharapkan tidak hanya current ratio dan quick ratio, namun variabel-variabel lain yang lebih berpengaruh terhadap return on asset.

\section{Referensi}

Arief Sugiono \& Edi Untung. (2016). Analisis Laporan Keuangan (PT Grasind). 
Fadli, A. A. Y. (2018). Pengaruh Current Ratio (Cr) Dan Debt To Total Asset Ratio (Dar) Terhadap Net Profit Margin (Npm) Pada Pt. Ultrajaya Milk Industri \& Trading Company Tbk Dan Pt. Mayora Indah Tbk Periode 2009 - 2016. Jurnal SEKURITAS (Saham, Ekonomi, Keuangan Dan Investasi), 2(1), 107-118.

Fahmi, I. (2015). Analisis Laporan Keuangan (Alfabeta).

Fahmi, I. (2016). Manajemen Sumber Daya Manusia Teori dan Aplikasi (Alfabeta).

Fajrin, P. H., \& Laily, N. (2016). Analisis Profitabilitas dan Likuiditas Terhadap Kinerja Keuangan PT. Indofood Sukses Makmur, Tbk. Jurnal Ilmu Dan Riset Manajemen, 5(6), 01-17.

Fauzi, F., Dencik, A. B., \& Asiati, D. I. (2019). Metodologi Penelitian untuk manajemen dan akuntansi. Jakarta: Salemba Empat.

Ghozali, imam. (2016). Aplikasi Analisis Multivariete dengan Program SPSS (Edisi 8. B).

Ghozali. (2014). Aplikasi Analisis Multivariate dengan Program SPSS (Badan Pene).

Ghozali. (2018). Aplikasi Analisis Multivariate dengan Program IBM SPSS 25 (Badan Pene).

Harmono. (2015). Manajemen Keuangan Berbasis Balanced Scorecard Pendekatan Teori, Kasus, dan Riset Bisnis (PT. Bumi A).

Herdiana, S. (2019). Analisis Pengaruh Current Ratio , Quick Ratio , dan Debt To Equity Ratio Terhadap Return on Asset pada Perusahaan Sektor Keuangan yang Terdaftar di Bursa Efek Indonesia Tahun 2016-2017.

Hery. (2015). Analisis Laporan keuangan (CAPS (Cent).

Hery. (2016). Analisis Laporan Keuangan (Grasindo).

Iswara, P. W. (2017). Pengaruh Rasio Likuiditas, Rasio Profitabilitas, Rasio Leverage, Ukuran Perusahaan, dan Asset Growth terhadap Kebijakan Dividen (Studi Kasus pada Perusahaan Industri Manufaktur Sub Sektor Makanan dan Minuman yang terdaftar di Bursa Efek Indonesia Periode. Jurnal Bisnis Dan Politeknik NSC Surabaya, 4(1), 3347.

Kasmir. (2015). Analisis laporan keuangan. PT Raja Grafindo Persada.

Miranda, R. N., \& Kharisma, F. (2020). Pengaruh Return On Assets dan Return On Equity Terhadap Harga Saham pada Perusahaan Consumer Goods yang Tercatat di BEI Periode Tahun 2013 -2017. Borneo Student Research, EISSN: 2721-5727, 1(3), 2009-2017.

Musthafa. (2017). Manajemen Keuangan (CV. Andi O).

Periansya. (2015). Analisis Laporan Keuangan (Politeknik).

Purnamasari, E. D. (2017). Analisis Pengaruh Laverage Terhadap Profitabilitas Perusahaan Yang Termasuk Lq45 Periode Agustus 2015-Januari 2016 Di Bursa Efek Indonesia. Jurnal Ilmiah Ekonomi Global Masa Kini, 8(1), 41-45.

Rahayu, A. S., \& Hari, M. (2016). Pengaruh Current Ratio dan Quick Ratio terhadap Kebijakan Dividen Melalui Return On Equity Pada Perusahaan Manufaktur yang Terdaftar di BEI Tahun 2014. Neliti: Jurnal Ekonomi Bisnis, 2, 231-239. 
Sabrina, N. (2020). Pengaruh Current Ratio (Cr) dan Debt To Equity Ratio Terhadap Return On Equity pada PT. Indah Kiat Pulp \& Paper, Tbk Periode 2012-2018. Wacana Ekonomi (Jurnal Ekonomi, Bisnis Dan Akuntansi), 19(2), 98-107.

Silvia, D. (2019). Pengaruh Likuiditas Terhadap Profitabilitas Pada Pt. Hero Supermarket Tbk Yang Terdaftar Di BEI Periode Tahun 2011-2019. Jurnal Akuntansi Dan Keuangan, $10(2), 1$.

Sugiyono. (2016). Metode Penelitian Kuantitatif, Kualitatif, R\&D. (IKAPI).

Sugiyono. (2017). Metode Penelitian Kuantitatif, Kualitatif dan R\&D (Alfabeta,).

Sujarweni, V. W. (2015). Akutansi Manajemen (Pustaka Ba).

Supardi, H., H. Suratno, H. S., \& Suyanto, S. (2018). Pengaruh Current Ratio, Debt To Asset Ratio, Total Asset Turnover Dan Inflasi Terhadap Return on Asset. JIAFE (Jurnal Ilmiah Akuntansi Fakultas Ekonomi), 2(2), 16-27.

Sutrisno, E. (2017). Manajemen Sumber Daya Manusia (Kencana).

Wahyuliza, S., \& Dewita, N. (2018). Pengaruh Likuiditas, Solvabilitas Dan Perputaran Modal Kerja Terhadap Profitabilitas Pada Perusahaan Manufaktur Yang Terdaftar Di Bursa Efek Indonesia. Jurnal Benefita, 3(2), 219.

Wurdianto, E., Chailis, I., \& Gemina, D. (2017). Pengaruh Current Ratio, Debt To Equity Ratio Dan Earning Per Share Terhadap Harga Saham Bank Umum Swasta Nasional Devisa Yang Terdaftar Di Bursa Efek Indonesia. Jurnal Sosial Humaniora, 8(1), 1

\section{Copyrights}

Copyright for this article is retained by the author(s), with first publication rights granted to the journal.

This is an open-access article distributed under the terms and conditions of the Creative Commons Attribution license (http://creativecommons.org/licenses/by/4.0/) 